\title{
Possible acaricidal activity of Jatropha curcas and Ricinus communis seed oils on Tetranychus urticae
}

\author{
Safaa A.S. Ghorab* and Manal S.M. Ismail ${ }^{* *}$ \\ ${ }^{*}$ Forestry and Timber Trees Dept., Horticulture Res. Inst, Agric. Res. Center, Egypt. \\ **Vegetable and Ornamental Plant Mites Dept., Plant Protec. Res. Inst., Agric. Res. Center, Egypt.
}

\begin{abstract}
Field evaluation for the acaricidal activity of jatropha (Jatropha curcas L.) and castor bean oils (Ricinus communis L.) against the nymphs and adults of the two-spotted spider mite, Tetranychus urticae on Alcea rosea L. conducted out in May 2016 on A. rosea in the experimental farm of the Faculty of Agriculture, Suez Canal University, Ismailia, Egypt. The fatty acids constituents of the two essential oils (from seeds) were identified by gas chromatography (GLC) analysis. The acaricidal activity of castor bean oil was higher than that of jatropha oil where the total population reduction rate of jatropha oil was $74.12 \%$ for adults and $75.19 \%$ for nymphs. Total population reduction rate of castor bean oil was $77.32 \%$ for adults; while it was $82.91 \%$ for nymphs on A. rosea leaves. Regarding flowers, the total population reduction rate of jatropha oil was $68.74 \%$ for adults; while it was $73.94 \%$ for nymphs but population reduction rate of castor bean oil was $72.33 \%$ for adults while it was $76.02 \%$ for nymphs. The major constituents of fatty acids identified by using GLC analysis in jatropha and castor bean oils were erucic $(44.34 \%)$ and ricinoleic acid $(41.75 \%)$, respectively. This study revealed that the essential oil of $J$. curcas and $R$. communis exhibited potent acaricidal activity against $T$. urticae which may be attributed to the presence of different bioactive compounds which may affect alone or in synergism.
\end{abstract}

Key words: Tetranychus urticae, jatropha oil, castor bean oil, GLC analysis, fatty acids, Alcea rosea.

\section{INTRODUCTION}

Tetranychus urticae (Acari: Tetranychidae) is a serious pest attacks broad range of ornamental plants specially, Alcea rosea L. (Ho, 2000 and Paramjit et al., 2006). Hollyhock, A. rosea L. (Malvales: Malvaceae) is a common ornamental plant cultivated at homeprivate gardens in Egypt (Johri, 2013). It is grown as a decorative plant and also known for its great medicinal uses (Ali Shah et al., 2011).

Mite control is still based primarily on the use of synthetic pesticides which lead to many problems. Thus, plants essential oils are ideal nomineesand can be potential alternative for mite control as some of them are selective, biodegradable, as well ecofriendly and economically viable (Tehri and Gulati, 2014).

Jatropha and castor bean are perennial, deciduous shrubs and well adapted to marginal soils. The oil, extracts of Jatropha curcas seeds has been used to control various pests in face of seeds are poisonous (Orwa et al., 2009).

As well, the castor bean oil extracted from the seeds of Ricinus communis has a considerable economic importance. It owns many medicinal properties (Scarpa and Guerci, 1982). Jatropha and castor bean oils proved to be have insecticidal activity against many pests (Kumar and Sharma, 2008 and Abd-Alla et al., 2015). Since different plant essential oils like sandalwood, cumine, clove, spearmint and Lippiasidoides essential oils have been found to be active against $T$. urticae worldwide (Cavalcanti et al., 2010 and Kheradmand et al., 2015), few studies dealt with the acaricidal effects of jatropha and castor bean oils (Abd-Alla et al., 2015 and Roy et al., 2016).

Therefore, the present study to characterize the fatty acids of the essential oils of $J$. curcas and $R$. communis for their chemical profiles and their possible acaricidal activities against $T$. urticae owing to its outbreak observed recently on A. rosea, in Egypt.

\section{MATERIALS AND METHODS}

\section{Collection of $J$. curcas and $R$. communis seeds and oil extraction}

Mature J. curcas and R. communis seeds were obtained from three years old shrubs. The seeds were heated by $70^{\circ} \mathrm{C}$ for $R$. communis only, wrapped in special bags and pressed using a compressor (KT23100EL) to extract the crude oil.

\section{Extraction of fatty acids:}

2.1. Lipid extraction and separation of fatty acids: Lipid extraction from samples by using chloroform/methanol $(2: 1 \mathrm{v} / \mathrm{v})$ was handled by method of A.O.A.C. (2000).The lipid samples were saponified with ethanolic $\mathrm{KOH}(20 \%)$ at room temperature over-night. Acidification with hydrochloric acid $(5 \mathrm{~N})$ were used to free the fatty acid from its potassium salts then extracted with petroleum ether at $40-60^{\circ} \mathrm{C}$. The extract was then washed three times by distilled water after; that dried over anhydrous sodium sulfate then filtered off. Finally, diazomethane was primed from methylamine hydrochloride as reported by Vogel (1975). 
2.2. Methylation of fatty acids with diazomethane:

Fatty acids extracted from lipid samples and standard fatty acids were dissolved in a little anhydrous methanol then added a small portion of the ethereal solution of diazomethane till gas evolution ceased. The excess diazomethane was added when the mixture gained the pale yellow color, then the reaction mixture was left for $10 \mathrm{~min}$ then under nitrogen stream, ether was evaporated at room temperature. After that, the fatty acids methyl esters was dissolved by two drops of redistilled chloroform solution, then this solution was injected into the gas chromatography (Vogel, 1975).

\subsection{Identification and determination of the fatty acids by gas liquid chromatography (GLC) analysis:}

Fatty acids were determined by GLC analysis according to Farag et al. (1986).Themethyl esters of fatty acids extracted from oil samples and the standard materials were analyzed by a Pye Unicam Series 304 gas chromatograph supplied with dual flame ionization detector and dual channel recorder. The fatty acid methyl esters separation was handled using a coiled glass column $(1.5 \mathrm{mx} 4 \mathrm{~mm})$ filled with Diatomite (100-120 mesh) and coated with 10\% polyethylene glycol adipate (PEGA). The column oven temperature was set at $8^{\circ} \mathrm{C} / \mathrm{min}$ from $70^{\circ} \mathrm{C}$ to $190^{\circ} \mathrm{C}$, after that isothermally at $190^{\circ} \mathrm{C}$ for $25 \mathrm{~min}$ with nitrogen at $30 \mathrm{ml} / \mathrm{min}$. Identification of peak was accomplished by comparing the retention time (RT) of each compound with those of standard materials.

\subsection{Chemical and physical properties of jatropha and castor bean oil:}

Acid value, iodine value, peroxide value and saponification value of the oils were determined according to the methods described by A.O.C.S. (1993) and refractive index was measured using an Abberre fractometer (C10, Vee Gee, USA).

\section{Bioassays:}

\section{Evaluation of acaricidal activity:}

The field trial was conducted out conducted in a randomized complete block design with 4 replications in May 2016 on A. rosea in the experimental Farm of the Faculty of Agriculture, Suez Canal University, Ismailia (Egypt). The treatments started at the presence of 5 mobile mites at least (adults and nymphs) on a plant. Three treatments $\left\{\mathrm{T}_{1}\right.$ : Triton X 100; $\mathrm{T}_{2}$ : Jatropha oil 15\%; $\mathrm{T}_{3}$ : Castor bean oil $15 \%$ \} with four replications were used on $A$. rosea. Distilled water having $0.05 \%$ Triton X100 only served as a control. Concentrations applied were selected after some initial tests. Treatments were applied by a hand-sprayer, as normally performed in open field; oils were sprayed at 7 a.m. uniformly on the two leaf blades (both from the top downwards and from below upwards) up to dripping (Piccinini et al., 2015).

Four leaves from each plant were sampled (4 leaves/plant $\times 8$ plants/treatment $\times 3$ treatments $\times 4$ replications). Samplings were conducted at 3, 5, 7, 14 and 21 days after treatment. The lower surface of the leaf and the flower were carefully examined, where live and dead individuals were recorded. Percentage reduction rates of adult and nymphal stages after treatments were estimated according to the equation of Henderson and Tilton (1955).

\section{RESULTS AND DISCUSSION}

The complete fatty acids profile and its peaks identified in jatropha oil by using GLC analysis were shown in Table (1). Erucic acid (44.34\%) represents the major constituent fatty acid in the oil followed by oleic acid (25.84\%), $\alpha$-linolenic acid (14.66\%), palmitic acid $(9.09 \%)$, stearic acid $(3.88 \%)$ and gondoic acid $(2.19 \%)$. This finding was in line with reports by Adebowale and Adedire (2006), Kumar and Sharma (2008), Akbar et al. (2009) and Cantrell et al. (2011). On the contrary, Lateef et al. (2014) found that the fatty acids contents of jatropha oil were 5-octodecenoic acid, 6-octadecenoic acid, myristic acid, 4-octadecenoic acid, pentadecanoic acid, 9, 12hexadecadienoic acid, palmitoleic acid, palmitic acid, arachidic acid, cyclopentanetridecanoic acid, oleic acid, margaric acid, linoleic acid, 15-octadecenoic acid,13-octadecenoic acid and stearic acid.

The complete fatty acids profile and its peaks identified in castor bean oil by using GLC analysis were shown in Table (2). Ricinoleic acid (41.75\%) represents the major constituent in the oil followed by linoleic acid (35.71\%), oleic acid (11.15\%), $\alpha$ linolenic acid $(7.85 \%)$, palmitic acid $(2.32 \%)$, linolenic acid $(0.72 \%)$, and gondoic acid $(0.51 \%)$. Similarly to our findings, Wafa et al. (2014)and Yusuf et al. (2015) showed that the ricinoleic acid $(74.10 \%)$ is the major constituent fatty acid followed by linoleic $(10.32 \%)$, oleic $(7.55 \%)$, stearic $(2.81 \%)$, palmitic $(2.59 \%)$, erucic $(1.70 \%)$ and eicosadienoic acids $(0.93 \%)$. Our results are in agreement with those reported by Akpan et al. (2006).

The fatty acids chemical compositions are a key factor in the acaricidal and/or insecticidal effects of any essential oils (Pascual-Villalobus and BallestaAcosta, 2003).The acid value, saponification value, iodine value and peroxide value are relatively high in jatropha oil (3.53, 115.74, 88.80 and 47 , respectively) as compared with castor bean oil $(1.26,100.98,76.14$ and 6.5, respectively) as shown in Table (3). The gondoic acid (C20:1) was identified in jatropha and 
Table (1): The fatty acids identified in jatropha oil by using GLC analysis.

\begin{tabular}{|c|c|c|c|c|c|c|c|}
\hline \multirow{2}{*}{ Peak } & \multirow{2}{*}{$\begin{array}{c}\text { Retention } \\
\text { Time(min) }\end{array}$} & \multicolumn{2}{|c|}{ Fatty acids } & \multirow{2}{*}{$\begin{array}{l}\text { Chemical } \\
\text { Formula }\end{array}$} & \multirow{2}{*}{$\begin{array}{c}\text { Lipid } \\
\text { Number }\end{array}$} & \multirow{2}{*}{$\begin{array}{l}\text { Density } \\
\left(\mathrm{g} / \mathrm{cm}^{3}\right)\end{array}$} & \multirow{2}{*}{$\begin{array}{c}\text { Area } \\
\text { Sum \% }\end{array}$} \\
\hline & & Chemical Name & Common Name & & & & \\
\hline 1 & 2.434 & 13- Docosenoic acid & Erucic acid & $\mathrm{C}_{22} \mathrm{H}_{42} \mathrm{O}_{2}$ & $\mathrm{C} 22: 1$ & 0.86 & 44.34 \\
\hline 2 & 22.245 & Hexadecanoic acid & Palmitic acid & $\mathrm{C}_{16} \mathrm{H}_{32} \mathrm{O}_{2}$ & C16:0 & 0.852 & 9.09 \\
\hline 3 & 29.525 & Cis-11-Eicosenoic acid & Gondoic acid & $\mathrm{C}_{20} \mathrm{H}_{38} \mathrm{O}_{2}$ & C20:1 & 0.883 & 2.19 \\
\hline 4 & 25.821 & Methyl stearate & Stearic acid, ethyl ester & $\mathrm{C}_{19} \mathrm{H}_{38} \mathrm{O}_{2}$ & C18:0 & 0.849 & 3.88 \\
\hline 5 & 26.288 & 9- Octadecenoic acid & Oleic acid & $\mathrm{C}_{18} \mathrm{H}_{34} \mathrm{O}_{2}$ & C18:1 & 0.895 & 25.84 \\
\hline 6 & 27.262 & 12,15- Octadecadienic acid & $\alpha$ - Linolenic acid & $\mathrm{C}_{18} \mathrm{H}_{30} \mathrm{O}_{2}$ & C18:3 & 0.916 & 14.66 \\
\hline
\end{tabular}

Table (2): The fatty acids identified in castor bean oil by using GLC analysis.

\begin{tabular}{|c|c|c|c|c|c|c|c|}
\hline \multirow{2}{*}{ Peak } & \multirow{2}{*}{$\begin{array}{l}\text { Retention } \\
\text { Time(min) }\end{array}$} & \multicolumn{2}{|c|}{ Fatty acid } & \multirow{2}{*}{$\begin{array}{l}\text { Chemical } \\
\text { Formula }\end{array}$} & \multirow{2}{*}{$\begin{array}{c}\text { Lipid } \\
\text { Number }\end{array}$} & \multirow{2}{*}{$\begin{array}{l}\text { Density } \\
\left(\mathrm{g} / \mathrm{cm}^{3}\right)\end{array}$} & \multirow{2}{*}{$\begin{array}{c}\text { Area } \\
\text { Sum \% }\end{array}$} \\
\hline & & Chemical Name & Common Name & & & & \\
\hline 1 & 22.293 & Hexadecanoic acid & Palmitic acid & $\mathrm{C}_{16} \mathrm{H}_{32} \mathrm{O}_{2}$ & C16:0 & 0.852 & 2.32 \\
\hline 2 & 26.546 & 9- Octadecenoic acid & Oleic acid & $\mathrm{C}_{18} \mathrm{H}_{34} \mathrm{O}_{2}$ & C18:1 & 0.895 & 11.15 \\
\hline 3 & 29.26 & $9,12-$ Octadecadienoic acid & Linoleic acid & $\mathrm{C}_{18} \mathrm{H}_{32} \mathrm{O}_{2}$ & C18:2 & 0.9 & 35.71 \\
\hline 4 & 28.639 & 9,12,15- Octadecatrienoic acid & Linolenic acid & $\mathrm{C}_{18} \mathrm{H}_{30} \mathrm{O}_{2}$ & C18:3 & 0.916 & 0.72 \\
\hline 5 & 29.622 & 12,15- Octadecadienoic acid & $\alpha$ - Linolenic acid & $\mathrm{C}_{18} \mathrm{H}_{30} \mathrm{O}_{2}$ & C18:3 & 0.916 & 7.85 \\
\hline 6 & 30.29 & 11- Eicosenoic acid & Gondoic acid & $\mathrm{C}_{20} \mathrm{H}_{38} \mathrm{O}_{2}$ & C20:1 & 0.883 & 0.51 \\
\hline 7 & 38.891 & Ricinoleic acid & Ricinoleic acid & $\mathrm{C}_{18} \mathrm{H}_{34} \mathrm{O}_{3}$ & C18:1 & 0.945 & 41.75 \\
\hline
\end{tabular}

Table (3): Chemical and physical properties of jatropha and castor bean seed oils

\begin{tabular}{lcc}
\multicolumn{1}{c}{ Parameter } & & Value \\
\cline { 2 - 3 } & Jatropha oil & Castor bean oil \\
\hline Acid Value $[\mathrm{mg} \mathrm{KOH} / \mathrm{g}]$ & $3.53 \pm 1.11$ & $1.26 \pm 0.11$ \\
\hline Saponification Value $[\mathrm{mg} \mathrm{KOH} / \mathrm{g}]$ & $115.74 \pm 1.09$ & $700.98 \pm 1.05$ \\
\hline Iodine Value $[\mathrm{g}$ Iodine/100g] & $88.80 \pm 1.10$ & $6.5 \pm 1.1$ \\
\hline Peroxide Value [ $\mathrm{meq} / \mathrm{kg}]$ & $47 \pm 2.0$ & $1.473 \pm 0.11$ \\
\hline Refractive Index at 25 or $28^{\circ} \mathrm{C}$ & $1.467 \pm 0.11$ & Amber Yellow \\
\hline Colour & Golden Yellow & \\
\hline
\end{tabular}

castor bean oils (2.19 and $0.51 \%$, respectively) with high molecular weight as shown in Tables (1 \& 2). Also, erucic acid (C22:1) (44.34\%) with high percentage and high molecular weight was identified in jatropha oil which may play a role in oil toxicity. According to Nabil and Yasser (2012), the insecticidal activity of J. curcas oil on Sitophilus granarius (Coleoptera) was related to the presence of high molecular weight fatty acids. Similar findings were also reported by Celestino et al. (2016) who stated that it might be a key factor in the insecticidal activity of the castor oil. This was in accordance with Khan et al. (1983) who found that the insect repellent activity of fixed oil of Annonas quamosa and Polyalthes longifolia were mainly due to the presence of high molecular weight fatty acids. This, confirming the present findings that the toxicity of jatropha and castor bean oils may be ascribed to the presence of high molecular weight fatty acids among other active agents.

Moreover, the major constituents of any essential oil are not the only components responsible for the toxic action and it is likely that these compounds act in synergy with the other secondary plant metabolites known also for their insecticidal properties (Lopez et al., 2008; Moraes et al., 2012 and Ribeiro et al., 2016). Essential oil constituents are predominantly lipophilic compounds that act as toxins, feeding and oviposition deterrents to different insect pests.

Although insecticidal activity of plant essential oils has been well described, very few works have been conducted in relation to the toxicity of jatropha and castor bean oils against $T$. urticae. Several reports have dealt with the use of essential oils from J. curcas to control insect pests. These comprise mosquitoes larvae (Cantrell et al., 2011), termites (Singh and Sushilkumar, 2008; Acda, 2009), diamondback moth (Kumrungsee et al., 2014), plants bugs (Ratnadass et al., 2009), S. granaries (Nabil and Yasser, 2012), adults of Coleoptera, Callosobruchus maculates (Boateng and Kusi, 2008). Nevertheless, it was used to control some ectoparasite mites (Dimri and Sharma, 2004). Castor bean oil was more recently used as a biocide for ticks Rhipicephalus sanguineus by preventing the development of oocytes (Sampieriet al., 2012), bacteria Leuconostocmes enteroides (Messetti et al., 2010), and also for ectoparasites (Leonardo et al., 2001).

The acaricidal activities of the two essential oils studied have been assessed and found toxic to $T$. urticae. Our results clearly confirm that both seed oils of $J$. curcas and R. communis significantly affected adult and nymphal stages of $T$. urticae. Population 
reduction rate and mean number $( \pm \mathrm{SE}) T$. urticae adults and nymphs after treatments with jatropha (15\%) and castor bean oils (15\%) on A. rosea leaves were summarized in Table (4). Jatropha oil achieved $66.6,72.7,78.3,76.9$ and $76.1 \%$ reduction of adult stage and $75.4,78.4,75.7,72.6$ and $73.9 \%$ reduction of nymph stage populations after 3, 5, 7, 14 and 21 days post treatments, respectively. Castor bean oil achieved 70.8, 95.9, 85.0, 72.1,62.8\%reduction of adult stage and 63.9, 97.8, 90.5, 87.4 and $75.0 \%$ reduction of nymph stage populations after $3,5,7,14$ and 21 days post treatments, respectively. The total population reduction rate of jatropha oil on adult stage was $74.12 \%$; while it was $77.32 \%$ for castor bean oil, respectively. But for nymphs, the total population, reduction rate of jatropha oil was $75.19 \%$ as compared to $82.91 \%$ for castor bean oil, respectively.

Population reduction rate and mean number $( \pm$ SE) of $T$. urticae adult and nymph stages after treatments with jatropha (15\%) and castor bean oil $(15 \%)$ on A. rosea flowers were summarized in Table (5). Jatropha oil achieved 55.6, 71.4, 81.7, 66.0 and $69.0 \%$ reduction of adult stage and 65.5, 90.5, 78.6, 62.4 and $72.8 \%$ of nymph stage populations after $3,5,7,14$ and 21 days post treatments, respectively. On the other hand, castor bean oil achieved total population reduction rate $65.9,82.6$, $76.2,70.9$ and $66.2 \%$ for adult stage and 66.4, $87.2,81.9,73.8$ and $70.8 \%$ reduction of nymph stage populations after 3, 5, 7, 14 and 21 days post treatments, respectively. The total population reduction rate of jatropha oil on adult stages was $68.74 \%$; while it was $73.94 \%$ for castor bean oil, respectively. But for nymphs, the total population reduction rate of jatropha oil was $72.33 \%$ as compared to $76.02 \%$ for castor bean oil, respectively.

Generally, the insecticidal effect of jatropha oil has been ascribed mainly to its phorbol ester fraction; it was up to 1-2\% (Makkar et al., 1998; Makkar and Becker, 2009). It is a tetracyclic deterpenoid that imitates the action of diacyl glycerol, activator of protein kinase $\mathrm{C}$ which adjusts many Cellular metabolic activities (Goel et al., 2007 and Katoune et al., 2011). Roy et al. (2016) found that jatropha oil has very strong insecticides and anti-mite properties against thrips and bugs of cowpea at $7.5 \%$ and tea red spider mite (Oligonychus coffeae), respectively. Similar findings were also reported in other studies showing the toxic effects of jatropha oil against insects where Habou et al. (2011) showed the insecticidal effect of $J$. curcas oil against aphids that attack Vicia fabae, and cowpea insect pests in fields. On cowpeas, $5 \%$ and $7.5 \%$ of J. curcas oil may reduce the level of attack by 10 and $50 \%$, respectively. Also, Lateef et al. (2014) showed that $J$. curcas phorbol esters possess a high level of insecticidal effect on the nymph and adult cockroaches and termites.

Table (4): Population reduction of T. urticae adult and nymph stages after treatments with jatropha (15\%) and castor bean oil (15\%) on Alcea rosea leaves.

\begin{tabular}{|c|c|c|c|c|c|c|c|c|c|c|c|c|}
\hline \multirow[b]{3}{*}{ Treatments } & \multirow{3}{*}{$\begin{array}{c}\begin{array}{c}\text { Before } \\
\text { Treatment }\end{array} \\
\text { Mean No. }\end{array}$} & \multicolumn{11}{|c|}{ After Treatments } \\
\hline & & \multicolumn{2}{|l|}{3 Days } & \multicolumn{2}{|l|}{5 Days } & \multicolumn{2}{|c|}{7 Days } & \multicolumn{2}{|c|}{14 Days } & \multicolumn{2}{|c|}{21 Days } & \multirow{2}{*}{$\begin{array}{c}\text { Total \% } \\
\text { Red. }\end{array}$} \\
\hline & & Mean No. & $\begin{array}{l}\text { Red. } \\
(\%)\end{array}$ & Mean No. & $\begin{array}{l}\text { Red. } \\
(\%)\end{array}$ & Mean No. & $\begin{array}{l}\text { Red. } \\
(\%)\end{array}$ & Mean No. & $\begin{array}{l}\text { Red. } \\
(\%)\end{array}$ & Mean No. & $\begin{array}{l}\text { Red. } \\
(\%)\end{array}$ & \\
\hline \multicolumn{13}{|c|}{ Adults } \\
\hline Jatropha oil 15\% & $34.88 \pm 3.34$ & $17.50 \pm 6.81$ & 66.6 & $13.38 \pm 2.43$ & 72.7 & $9.38 \pm 0.63$ & 78.3 & $7.88 \pm 1.79$ & 76.9 & $8.5 \pm 2.42$ & 76.1 & 74.12 \\
\hline Castorbeanoil15\% & $41.00 \pm 7.62$ & $18.00 \pm 2.90$ & 70.8 & $2.38 \pm 0.26$ & 95.9 & $6.50 \pm 1.69$ & 85.0 & $9.50 \pm 1.75$ & 72.1 & $13.25 \pm 1.75$ & 62.8 & 77.32 \\
\hline Control & $48.88 \pm 2.65$ & $73.38 \pm 8.80$ & - & $68.63 \pm 7.04$ & - & $60.63 \pm 11.19$ & - & $47.75 \pm 4.90$ & - & $50.14 \pm 5.70$ & - & - \\
\hline \multicolumn{13}{|c|}{ Nymphs } \\
\hline Jatropha oil $15 \%$ & $85.75 \pm 9.07$ & $34.88 \pm 14.02$ & 75.4 & $29.00 \pm 6.87$ & 78.4 & $33.63 \pm 4.78$ & 75.7 & $32.88 \pm 11.98$ & 72.6 & $19.50 \pm 8.15$ & 73.9 & 75.19 \\
\hline Castorbeanoil $15 \%$ & $188.13 \pm 35.61$ & $112.38 \pm 19.78$ & 63.9 & $6.38 \pm 0.73$ & 97.8 & $28.88 \pm 1.33$ & 90.5 & $33.13 \pm 6.64$ & 87.4 & $41.00 \pm 7.88$ & 75.0 & 82.91 \\
\hline Control & $102.63 \pm 9.98$ & $169.63 \pm 24.01$ & - & $160.50 \pm 27.69$ & - & $165.88 \pm 29.18$ & - & $143.38 \pm 16.64$ & - & $89.57 \pm 18.08$ & - & - \\
\hline
\end{tabular}

Table (5): Population reduction \% of T. urticae adults and nymphs after treatments with jatropha (15\%) and castor bean oil( $15 \%)$ on Alcea rosea flowers.

\begin{tabular}{|c|c|c|c|c|c|c|c|c|c|c|c|c|}
\hline \multirow[b]{3}{*}{ Treatments } & \multirow{3}{*}{$\begin{array}{c}\begin{array}{c}\text { Before } \\
\text { Treatment }\end{array} \\
\text { Mean No. }\end{array}$} & \multicolumn{11}{|c|}{ After Treatments } \\
\hline & & \multicolumn{2}{|l|}{3 Days } & \multicolumn{2}{|c|}{5 Days } & \multicolumn{2}{|c|}{7 Days } & \multicolumn{2}{|c|}{14 Days } & \multicolumn{2}{|c|}{21 Days } & \\
\hline & & Mean No. & $\begin{array}{l}\text { Red. } \\
(\%)\end{array}$ & Mean No. & $\begin{array}{l}\text { Red. } \\
(\%)\end{array}$ & Mean No. & $\begin{array}{l}\text { Red. } \\
(\%)\end{array}$ & Mean No. & $\begin{array}{l}\text { Red. } \\
(\%)\end{array}$ & Mean No. & $\begin{array}{l}\text { Red. } \\
(\%)\end{array}$ & \\
\hline \multicolumn{13}{|c|}{ Adults } \\
\hline Jatropha oil 15\% & $10.00 \pm 1.15$ & $4.00 \pm 0.46$ & 55.6 & $1.63 \pm 0.38$ & 71.4 & $1.25 \pm 0.45$ & 81.7 & $2.63 \pm 0.49$ & 66.0 & $2.75 \pm 0.92$ & 69.0 & 68.74 \\
\hline Castorbeanoil15\% & $11.38 \pm 1.43$ & $3.50 \pm 0.46$ & 65.9 & $1.13 \pm 0.35$ & 82.6 & $1.63 \pm 0.56$ & 76.2 & $2.25 \pm 0.65$ & 70.9 & $3.00 \pm 0.70$ & 66.2 & 72.33 \\
\hline Control & $16.50 \pm 1.61$ & $14.88 \pm 1.41$ & - & $9.38 \pm 0.65$ & - & $11.25 \pm 1.01$ & - & $12.75 \pm 1.44$ & - & $14.57 \pm 3.47$ & - & - \\
\hline \multicolumn{13}{|c|}{ Nymphs } \\
\hline Jatropha oil $15 \%$ & $15.38 \pm 2.04$ & $6.00 \pm 0.87$ & 65.5 & $1.50 \pm 0.33$ & 90.5 & $3.25 \pm 0.65$ & 78.6 & $4.63 \pm 0.73$ & 62.4 & $3.00 \pm 0.93$ & 72.8 & 73.94 \\
\hline Castorbeanoil 15\% & $16.13 \pm 2.07$ & $6.13 \pm 1.11$ & 66.4 & $2.13 \pm 0.51$ & 87.2 & $2.88 \pm 0.72$ & 81.9 & $3.38 \pm 0.89$ & 73.8 & $3.38 \pm 0.88$ & 70.8 & 76.02 \\
\hline Control & $36.13 \pm 3.89$ & $40.88 \pm 3.23$ & - & $37.13 \pm 1.83$ & - & $35.63 \pm 5.03$ & - & $28.88 \pm 5.36$ & - & $25.86 \pm 5.35$ & - & - \\
\hline
\end{tabular}


Our data demonstrated that the castor bean oil recorded higher acaricidal activity than that of jatropha oil with the same concentration for nymph and adult stages on both leaves and flowers of $A$. rosea. This was in agreement with Abd-Alla et al. (2015) who studied the acaricidal activities of two local cultivars of $R$. communis against $T$. urticae in Egypt. In contrast, Alonso and Santos (2013) evaluated and analyzed the toxic action and deterrent properties of castor bean and jatropha oil against workers of the leaf-cutting ant (Atta sexdens) in laboratory and found that jatropha oil exerted more toxic effects than castor bean oil. The previous studies showed that toxicity of castor oils against different insects was related to ricinoleic acid $(87-90 \%)$ (Akpan et al., 2006 and Conceicao et al., 2007).This observation was in line with our study and with earlier reports by Morehouse et al. (1986) who stated that ricinoleic acid is the active component of castor bean oil.

The mode of action of essential oil compounds is also not fully understood, but they elicit characteristic neurotoxic symptoms including agitation, hyperactivity, paralysis and knockdown (Koul et al., 2008). In this aspect, the acaricidal activity of the essential oils used in our study could be due tophorbol ester, ricinoleic acid or other high molecular weight fatty acids like gondoic or erucic acids or other bioactive compounds which may affect alone or in synergism for jatropha and castor bean oils, respectively.

In conclusion, the use of natural products may be considered as important alternative acaricide to control this pest, since it constitute a rich source of bioactive compounds that are biodegradable, nontoxic, and their effects might be either the result of a synergism of all molecules or could reflect only those of the main molecules. However, the cost of the essential oil may also be an important factor for its implementation, which depends on the availability of the plant and its yield. In accordance with the present conclusions, castor bean essential oil may be used as an ecologically safe alternative pesticide against $T$. urticae followed by jatropha oil. Also, we need to separate the active ingredients of the oils tested, and then evaluate its acaricidal activities on the different life stages of the T. urticae.

\section{REFERENCES}

A.O.C.S. 1993. Official methods and recommended practices of the American Oil Chemists' Society, AOCS Press. Washington, D.C.

A.O.A.C. 2000. Official Methods of Analysis of the Association of Official Analytical Chemists. $14^{\text {th }}$ ed Washington, D.C.

Abd-Alla, H. I.; Elnenaey, H. M.; Hassan, A. Z.; Taie, H. A.; Abo-Shnaf, R. I. and Hussein, A. M. 2015. Bioactive metabolites from two local cultivars of Ricinus communis and their free radical scavenging and acaricidal activities. Der Pharma Chemica, 7(4): 5-18.

Acda, M. N. 2009. Toxicity, tunneling and feeding behavior of the termite, Coptotermes vastator, in sand treated with oil of the physic nut, Jatropha curcas. Journal of Insect Science, 9: 1-8.

Adebowale, K. O. and Adedire, C. O. 2006. Chemical composition and insecticidal properties of the underutilized Jatropha curcas seed oil. African Journal of Biotechnology, 5: 901-906.

Akbar, E.; Yaakob, Z.; Kamarudin, S. K.; Ismail, M. and Salimon, J. 2009. Characteristic and composition of Jatropha curcas oil seed from Malaysia and its potential as biodiesel feedstock. European Journal of Scientific Research, 29(3): 396-403.

Akpan, U. G.; Jimoh, A. and Mohammed, A. D. 2006. Extraction, characterization and modification of castor seed oil. Leonardo Journal of Sciences, (8): 43-52.

Ali Shah, S. M.; Akhtar, N.; Akram, M.; Akhtar Shah, P.; Saeed, T.; Ahmed, K. and Asif, H. M. 2011. Pharmacological activity of Althaea officinalis L. Journal of Medicinal Plants Research, 5(24): 5662-5666.

Alonso, E. C. and Santos, D. Y. A. C. 2013. Ricinus communis and Jatropha curcas (Euphorbiaceae) seed oil toxicity against Atta sexdens rubropilosa (Hymenoptera: Formicidae). Journal of Economic Entomology, 106 (2): 742-746.

Boateng, B. A. and Kusi, F. 2008. Toxicity of jatropha seed oil to Callosobruchus maculatus (Coleoptera: Bruchidae) and its parasitoid, Dinarmus basalis (Hymenoptera: Pteromalidae). Journal of Applied Sciences Research, 4: 945951.

Cantrell, C. L.; Ali, A.; Duke, S. O. and Khan, I. 2011. Identification of mosquito biting deterrent constituents from the Indian folk remedy plant Jatropha curcas. Journal of Medical Entomology, 48: 836-845.

Cavalcanti, S. C. H.; Niculau, E. D. S.; Blank, A. F.; Câmara, C. A. G.; Araújo, I. N. and Alves, P. B. 2010. Composition and acaricidal activity of Lippiasidoides essential oil against two-spotted spider mite (Tetranychus urticae Koch). Bioresource Technology, 101(2): 829-832.

Celestino, F. N.; Pratissoli, D.; Machado, L. C.; Junior, H. J. G. S.; Queiroz, V. T. and Mardgan, L. 2016. Control of coffee berry borer, Hypothenemus hampei (Ferrari)Maringá, Acta 
Scientiarum Agronomy, 38(1): 1-8.

Conceicao, M. M.; Fernandes Jr., V. J.; Bezerra, A. F.; Silva, M. C. D.; Santos, I. M. G.; Silva, F. C. and Souza, A. G. 2007a. Dynamic kinetic calculations of castor oil biodiesel. Journal of Thermal Analysis and Calorimetry, 87: 865-869.

Dimri, U. and Sharma, M. C. 2004. Effects of sarcoptic mange and its control with oil of Cedrus deodara, Pongamia glabra, Jatropha curcas and benzyl benzoate, both with and without ascorbic acid on growing sheep: Epidemiology; assessment of clinical, haematological, cell-mediated humoral immune responses and pathology. Transboundary and Emerging Diseases, 55(12):71-78.

Farag, R. S.; Hallabo, S. A. S.; Hewedi, F. M. and Basyony, A. E. 1986. Chemical evaluation of Rape seed. European Journal of Lipid Science and Technology, 88(10): 391-397.

Goel, G.; Harinder, P.; Makkar, S. and Francis Becker, G. K. 2007. Phorbol esters: structure, biological activity, and toxicity in animals. International Journal of Toxicology, 26: 279-288.

Habou, Z. A.; Haougui, A.; Mergeai, G.; Haubruge, E.; Toudou, A. and Verheggen, F. J. 2011.Insecticidal Effect of Jatropha curcas oil on the aphid Aphis fabae (Hemiptera: Aphididae) and on the main insect pests associated with cowpeas (Vignaun guiculata) in Niger. Tropicultura, 29(4): 225-229

Henderson, C. F. and Tilton, E. W. 1955.Tests with acaricides against the brown wheat mite. Journal of Economic Entomology, 48: 157-161.

Ho, C. C. 2000. Spider mite problems and control in Taiwan. Experimental and Applied Acarology, 24: 453-462.

Johri, A. 2013. Epidermal characters of some ornamental plants used in traditional medicine. Academy of Plant Sciences, 26(1): 153-155.

Katoune, H. I.; Lafia, D. M.; Salha, H.; Doumma, A.; Drame, A. Y.;Pasternak, D. and Ratnadass, A. 2011. Physic nut (Jatropha curcas) oil as a protect ant against field insect pests of cowpea in SudanoSahelian cropping systems. Journal of SAT Agricultural Research, 9:1-6.

Khan, W. M.; Ahmad, D.; Ahmad, I. and Osman, S. M. 1983. Nonedible seed oils as insect repellant. Journal of the American Oil Chemist's Society, 60(5): 949-950.

Kheradmand, K.; Beynaghi, S.; Asgari, S. and Sheikhigarjan, A. 2015. Toxicity and repellency effects of three plant essential oils against twospotted spider mite, Tetranychus urticae (Acari: Tetranychidae). Journal of Agricultural Science and Technology, 17(5): 1223-1232.

Koul, O.; Walia, S. and Dhaliwal, G. S. 2008. Essential oils as green pesticides: potential and constraints. Biopesticides International,
$4(1): 63-84$.

Kumar, A. and Sharma, S. 2008. An evaluation of multipurpose oil seed crop for industrial uses (Jatropha curcas L.): a review. Industrial crops and products, 28(1): 1-10.

Kumrungsee, N.; Pluempanupat, W.; Koul, O. and Bullangpoti, V. 2014. Toxicity of essential oil compounds against diamondback moth, Plutellax ylostella, and their impact on detoxification enzyme activities. Journal of Pest Science, 87: 721-729.

Lateef, F. A.; Daudu, S. O.; Jere, P. and Yusuf, D. 2014. Insecticidal effect of Jatropha curcas oil phorbol esters on the nymph, adult cockroaches and termites. International Journal of Applied Science and Engineering Resources, 3(2): 495503.

Leonardo, M. R.; Silva, L. A. B.; TanomaruFilho, M.; Bonifacio, K. C. and Ito, I. Y. 2001. In vitro evaluation of the antimicrobial activity of a castor oil-based irrigant. Journal of Endodontics, 27: 717-719.

Lopez, M. D.; Jordan, M. J. and Pascual-Villalobos, M. J. 2008.Toxic compounds in essential oils of coriander, caraway and basil active against stored rice pests. Journal of Stored Products Research, 44: 273-278.

Makkar, H. P. and Becker, K. 2009. Jatropha curcas, a promising crop for the generation of biodiesel and value-added coproducts. European Journal of Lipid Science and Technology, 111(8): 773-787.

Makkar, H. P. S.; Aderibigbe, A. O. and Becker, K. 1998.Comparative evaluation of non-toxic and toxic varieties of Jatropha curcas for chemical composition, digestibility, protein degradability and toxic factors. Food Chemistry, 62(2): 207215.

Messetti, M. A.; dos Santos, A. M.; de Angelis, D. F.; Chierice, G. O. and Claro, N. 2010. Study of a Ricinus communis L. (Castor oil) derivative as a biocidal agent and viscosity reducer on Leuconostocmes enteroides in the sugar and alcohol industries. Arquivos do Instituto Biológico, 77(2): 301-308.

Moraes, M. M.; da Câmara, C. A.G.; Santos, M. L. and Christopher, F. A. G. G. 2012. Essential oil composition of Eugenia langsdorffii O. Berg.: Relationships between some terpenoids and toxicity against Tetranychus urticae. Journal of Brazilian Chemical Society, 23: 1647-1656.

Morehouse, J. L.; Specian J. L.; Stewart J. L. and Berg J. L. 1986. Translocation indigenous bacteria gastrointestinal tract mice after oral ricinoleic acid treatment. Gastroenterology, 91: 673-682.

Nabil, A. E. A. and Yasser, A. M. K. 2012. Jatropha curcas oil as insecticide and germination promoter. Journal of Applied Sciences Research, 
45: 668-675.

Paramjit, K.; Dhooria, M. S. and Bhullar, M. B. 2006. Suitability of different flowering annuals as hosts of two-spotted spider mite, Tetranychus urticae Koch. Journal of Applied Zoological Researches, 17(1): 24-28.

Pascual-Villalobus, M. J. and Ballesta-Acosta, M. C. 2003. Chemical variation in an Ocimum basilicum germplasm collection and activity of the essential oil on Collosobruchus maculatus. Biochemical Systematics and Ecology, 31: 673-679.

Piccinini, E.; Ferrari, V.; Campanelli, G.; Fusari, F.; Righetti, L.; Matteo, R. and Lazzeri, L. 2015. Effect of two bio-based liquid formulations from Brassica carinata in containing red spider mite (Tetranychus urticae) on eggplant. Industrial Crops and Products, 75: 36-41.

Ratnadass, A. and Wink, M. 2012. The Phorbol Ester Fraction from Jatropha curcas Seed Oil: Potential and Limits for Crop Protection against Insect Pests. International Journal of Molecular Sciences, 13: 16157-16171.

Ratnadass, A.; Togola, M.; Cisse, B. and Vassal, J. M. 2009. Potential of sorghum and physic nut (Jatropha curcas) for management of plant bugs (Hemiptera: Miridae) and cotton bollworm (Helicoverpaar migera) on cotton in an assisted trap-cropping strategy. Journal of SAT Agricultural Research, 7: 1-7.

Ribeiro, N.; Camara, C. and Ramos, C. 2016. Toxicity of essential oils of Piper marginatum Jacq. Against Tetranychus urticae Koch and Neoseiulus californicus (McGregor). Chilean Journal of Agricultural Research, 76(1): 71-76.

Roy, S.; Handique, G.; Barua, A.; Bora, F. R.; Rahman, A. and Muraleedharan, N. 2016. Comparative performances of jatropha oil and garlic oil with synthetic acaricides against red spider mite infesting tea. Proceedings of the National Academy of Sciences, India Section B:
Biological Sciences, 1-7.

Sampieri, B. R.; Arnosti, A.; Furquim, K. C. S.; Chierice, G. O.; Bechara, G. H.; de Carvalho P. L. P. F.; Nunes, P. H. and Camargo-Mathias, M. I. 2012. Effect of ricinoleic acid esters from castor oil (Ricinus communis) on the oocyte yolk components of the tick Rhipicephalus sanguineus (Latreille, 1806) (Acari: Ixodidae). Veterinary Parasitology, 191(3): 315-322.

Scarpa, A. and Guerci, A. 1982. Various uses of the castor-oil plant (Ricinus communis $\mathrm{L}$ ) - a review. Journal of Ethnopharmacology, 5: 117-137.

Senthilkumar, N.; Varma, P. and Gurusubramanian, G. 2009.Larvicidal and adulticidal activities of some medicinal plants against the malarial vector, Anopheles stephensi (Liston). Parasitology Research, 104(2): 237-244.

Singh, N. and Sushilkumar, A. 2008. Anti termite activity of Jatropha curcas Linn. Biochemicals. Journal of Applied Sciences and Environmental Management, 12: 67-69.

Tehri, K. and Gulati, R. 2014. Field efficacy of some biorationals against the two spotted spider mite Tetranychus urticae Koch (Acari: Tetranychidae). Journal of Applied and Natural Science, 6(1): 62-67.

Vogel, A. J. 1975. A text book of practical organic chemistry. $3^{\text {rd }}$ ed. P. 969-971, English Language Book Society and Longman Group Ltd. London.

Wafa, G.; Amadou, D. and Larbi, K. M. 2014. Larvicidal activity, phytochemical composition, and antioxidant properties of different parts of five populations of Ricinus communis L. Industrial Crops and Products, 56: 43-51.

Yusuf, A. K.; Mamza, P. A. P.; Ahmed, A. S. and Agunwa, U. 2015. Extraction and characterization of castor seed oil from wild Ricinus communis Linn. Int. International Journal of Science, Environment and Technology, 4(5): 1392-1404. 